\title{
IMPROVEMENT OF SEXUAL AND REPRODUCTIVE FUNCTION IN MEN WITH SPINAL CORD LESION
}

\author{
Miro Kasum ${ }^{1,6}$, Slavko Orešković ${ }^{1}$, Mario Kordić ${ }^{2}$, Ermin Čehić ${ }^{3}$, \\ Dinko Hauptman ${ }^{4}$, Emina Ejubović ${ }^{3}$, Albert Lila ${ }^{5}$ and Gordana Smolčić ${ }^{1}$
}

${ }^{1}$ University Department of Obstetrics and Gynecology, Zagreb University Hospital Centre, School of Medicine, University of Zagreb, Zagreb, Croatia; ${ }^{2}$ Department of Urology, Mostar University Clinical Hospital, Mostar, Bosnia and Herzegovina; ${ }^{3}$ Department of Obstetrics and Gynecology, Zenica Cantonal Hospital, Zenica, Bosnia and Herzegovina; ${ }^{4}$ Department of Urology, Zagreb University Hospital Centre, School of Medicine, University of Zagreb, Zagreb, Croatia; ${ }^{5}$ Kosovo Occupational Health Institute, Giakove, Kosovo; ${ }^{6}$ School of Medicine, University of Zagreb, Zagreb, Croatia

SUMMARY - The aim of the review is to establish sexual and reproductive functions in men with spinal cord lesion (SCL). Many sexual and reproductive dysfunctions may be found in these patients including individual's low self-esteem, delay of orgasm, erectile or ejaculatory disorder and abnormalities of semen, which are characterized by lower sperm motility or viability. Owing to improvements in physical medicine and rehabilitation, the focus has been shifted from keeping patients alive towards ensuring the quality of life and improvements of sexual dysfunctions and later reproduction. Erectile dysfunction can be treated by using phosphodiesterase- 5 inhibitors, intracavernosal injections, vacuum devices and penile prostheses. Semen can be retrieved from anejaculatory patients by medically assisted methods utilizing penile vibratory stimulation, electroejaculation, prostate massage, or surgically. Although there is low chance for pregnancy in natural way in most of SCL patients, fatherhood is possible through the introduction of assisted medical management. By use of various medical, technical and surgical procedures for sperm retrieval combined with assisted reproductive methods, high pregnancy rates have been reported comparable to those in able-bodied subfertile patients. Nevertheless, future studies are needed to improve semen quality and methods of assisted ejaculation in patients with SCL.

Key words: Spinal cord injuries; Male; Sexual dysfunction, physiological - therapy; Erectile dysfunction - therapy; Sperm retrieval; Sperm motility; Pregnancy rate; Quality of life

\section{Introduction}

Spinal cord lesion (SCL) is a serious traumatic event that impacts the patient's physical, psychological and social well-being and places substantial financial burden on health care systems, which has been increasing over years worldwide, especially in the United

Correspondence to: Prof. Miro Kasum, MD, PhD, University Department of Obstetrics and Gynecology, School of Medicine, Zagreb University Hospital Center, Petrova 13, HR-10000 Zagreb, Croatia

E-mail: mkasum@gmail.com

Received July 7,2016, accepted December 12, 2016
States of America. Epidemiologic data on SCL have been reported from 41 countries, mostly European and high-income countries, whereas such data are lacking for African and Asian countries. The prevalence of SCL is highest in the United States of America (906 per million) and lowest in the Rhone-Alpes region in France (250 per million) and Helsinki, Finland (280 per million). The highest reported annual incidence of SCL per million is recorded in Alaska $(\mathrm{N}=83)$ and Mississippi $(\mathrm{N}=77)$ and lowest in Fiji $(\mathrm{N}=10)$ and Spain $(\mathrm{N}=8)$. Traffic accidents are typically the most common cause of SCL, followed by falls in the elderly population. The majority of studies in persons with 
SCL have shown a high male-to-female ratio. In most regions and countries, a larger percentage of SCL patients are under the age of $30^{1}$.

Although there are still no procedures that can reverse neurological impairment in patients with SCL, the rehabilitation management by specialized SCL teams of physicians, nurses, therapists, social workers and psychologists immediately following SCL has become the standard of care throughout the world. Advances in the rehabilitation management of SCL have led to remarkable improvements including higher survival rates, improved physical fitness, shorter hospitalization, and more effective treatment for spasticity and neuropathic pain. Furthermore, modern treatment has improved the mobility of such patients, facilitating their access to information and socialization, and focusing on their quality of life, sexual or reproductive function ${ }^{2}$.

However, many aspects of sexuality can be altered in men with SCL including interference with positioning and mobility, unexpected problems with incontinence and spasticity, erectile function essential for intercourse, decreased pleasure and delay of orgasm, as well as ejaculation necessary for fertility. Sexual dysfunction varies as a consequence of complete or incomplete spinal lesions, and despite concomitant $\mathrm{pa}^{-}$ ralysis and loss of sensation, sexual treatment should be offered and integrated with the individual's remaining sexual potential, in accordance with active rehabilitation. Owing to the use of current treatment modalities that are available to the general population, such as phosphodiesterase-5 (PDE-5) inhibitors, intracavernosal injections, vacuum devices and penile prostheses, these problems can be managed successfully because spinal cord injured men can achieve satisfaction with their sexual life (54\%), erection (75\%), ejaculation (44\%) and pregnancy (19\%) 3 . Assessment of sexual function and satisfaction in men with SCL by using the Male Sexual Quotient has revealed that erectile function, ejaculation, and orgasm are most severely disturbed despite increased sexual interests ${ }^{4}$. Furthermore, such patients have preserved interest in maintaining later reproductive capability, although their rates of sexual and fecundity dysfunctions remain high $^{5}$. Unfortunately, it is well known that following SCL, most of these patients are infertile due to disruption of sacral autonomic nerves, with consequent erectile dysfunction, ejaculatory dysfunction and semen abnormalities. Although a great majority of these men cannot father own children naturally via sexual intercourse, fatherhood is still possible owing to the use of specialized medical management of erectile and ejaculatory disorders including penile vibratory stimulation (PVS), electroejaculation (EEJ), via prostate massage, or surgically. Numerous studies have reported high pregnancy rates by use of various assisted methods for sperm retrieval in men with SCL combined with assisted reproductive techniques (ART), which are comparable to those in able-bodied sub-fertile patients ${ }^{6-13}$. The aim of the review is to establish sexual and reproductive functions and current management with a view on the outcome of pregnancy in men with SCL.

\section{Erectile Dysfunction}

In spinal cord injured patients, psychogenic and reflexogenic erections are often disturbed despite normal vascular and anatomic functions ${ }^{14}$. Since the basic mechanisms responsible for erection including normal vasculature and intact $\mathrm{S} 2-\mathrm{S} 4$ reflex arc are usually preserved, patients with SCL respond quite well to oral administration of PDE-5 inhibitors such as tadalafil, sildenafil and vardenafil, by inhibiting degradation of cyclic guanosine monophosphate in the penile corpora and resulting in vascular smooth muscle relaxation ${ }^{15}$. In addition, intracavernosal injections with phentolamine, papaverine and alprostadil have been used successfully (80\%) for improvement of erectile dysfunction by releasing higher levels of cyclic adenosine monophosphate, another potent dilatator, despite undesirable side effects such as priapism and hematoma ${ }^{16}$. Another local treatment of erectile dysfunction includes the use of the medicated urethral system for erection (MUSE) with intraurethral application of alprostadil, which is less invasive and therefore preferred despite variable absorption of the drug from the urethral lumen, which can reduce its effectiveness ${ }^{17}$. Vacuum erection devices consist of a rigid cylinder for penile inserting and a constriction band over the base of the penis, forming the mechanism of negative pressure to draw and maintain blood in the penis. Nevertheless, in patients with SCL, lower satisfaction rates with vacuum erection devices have been reported compared to other methods for erectile dysfunction ${ }^{18}$. Another attractive option for erectile dysfunction is a surgically implanted malleable penile prosthesis, which is char- 
acterized with an overall patient satisfaction rate of $79.2 \%{ }^{19}$. It seems that the three-piece inflatable penile prosthesis has the highest patient satisfaction rates and lowest mechanical revision rates ${ }^{20}$. Furthermore, alternative surgical procedures for erectile dysfunction including Brindley sacral anterior root stimulator after sacral dorsal rhizotomy have also been reported recently, but with varying degrees of effectiveness ${ }^{21}$.

\section{Ejaculatory Dysfunction}

The ejaculatory reflex consists of emission and expulsion; it is controlled by a spinal cord generator from thoracolumbar sympathetic (T10-L2) and sacral somatic (S2-S4) segments, as well as somatic inputs from the dorsal nerve of the penis ${ }^{22}$. Additionally, the spinal ejaculation generator is under inhibitory and excitatory influence of supraspinal sites, including the paragigantocellular nucleus, the paraventricular nucleus of the hypothalamus, and the medial preoptic area ${ }^{23}$. Therefore, spinal injuries below T10 can lead to disruption of the nerve pathways and ejaculatory dysfunction, which vary according to the size of lesion and location, but an injury at or above the neurological T10 is quite innocent considering the reflex necessary for ejaculation ${ }^{24}$. Since in the majority of cases with SCL it is impossible to achieve ejaculation by masturbation, semen retrieval can be done by application of various medically assisted methods ${ }^{8}$.

Penile vibratory stimulation is preferred by most patients with SCL and it is usually recommended at the beginning of treatment for ejaculatory disorders because it is noninvasive, simple for use, safe, cost-effective and reliable compared with other techniques ${ }^{7,8}$. A vibrator is usually applied on the dorsum or frenulum of the glans penis for several minutes and repeated for up to 10 minutes of stimulation or until antegrade ejaculation occurs. In cases when the use of a single vibrator such as the FertilCare or Viberect fail to induce ejaculation, the choice of devices with two vibrators or concomitant use of electrical abdominal and vibratory stimulation may be effective. Although the success rate of the Viberect is lower (77\%) than that reported for the FertilCare device (86\%) in patients with spinal injuries rostral to $\mathrm{T} 10$, the ejaculatory rate of the FertilCare device is much lower (17\%) in cases with spinal lesions caudal to this level ${ }^{25-28}$.

Electroejaculation applies electrical current through the rectum in patients with SCL who do not respond successfully to PVS, by stimulating the nerves and smooth muscles of the prostate with seminal vesicles, as well as pelvic muscles. However, if antegrade ejaculation fails, retrograde ejaculation often appears and therefore a catheter need to be introduced through the penis to collect residual semen from the bladder. Furthermore, in cases when no sperm is found in the pellet of centrifuged specimen, the bladder should be lavaged with a sperm washing buffer ${ }^{7}$. Among different techniques used for EEJ, it was found that a higher proportion of sperm could be retrieved in the antegrade fraction using the interrupted method, compared with continuous delivery of EEJ, although each method results in a similar mean total sperm number and total motile sperm in the ejaculate. Consequently, the intermittent method should be regarded as the technique of choice in cases when EEJ is used to retrieve sperm for fertilization. In the majority of patients with spinal cord injury, anesthesia is not required during EEJ, except for cases with preserved pelvic sensation where conscious sedation or general anesthesia may be used. EEJ is a highly effective technique with the ejaculatory success rate of $95 \%$. Nevertheless, the failure rate of $5 \%$ may be attributable to patients with pelvic pain on the first trial of EEJ and those that do not want to go on with additional trials under general anesthesia or sedation ${ }^{29-31}$.

Prostate massage is a simple technique of semen retrieval, which is performed through the patient's rectum with a finger pressing on the prostate and seminal vesicles. It is usually used prior to surgical trials in cases when PVS fails or inability to perform EEJ. Unfortunately, its use is unclear because sperm yields are often lower $(<32 \%)$ than with PVS or EEJ ${ }^{7,32}$.

Surgical sperm retrieval in patients with SCL is performed by aspiration or surgically from reproductive tissue by use of several surgical procedures including percutaneous epididymal sperm aspiration (PESA), microepididymal sperm aspiration (MESA), testicular sperm aspiration (TESA), testicular sperm extraction (TESE), microdissection testicular sperm extraction (micro-TESE) and aspiration of sperms from the vas deferens ${ }^{24}$. An algorithm for sperm retrieval based on the study of 3152 semen retrieval trials in men with SCL suggests that in cases when PVS fails, EEJ should be used, but when EEJ is contraindicated or fails, prostate massage or surgical sperm retrieval may be performed ${ }^{28}$. Nevertheless, due to lower sperm yields and 
the motile sperm count obtained with these surgical techniques, ART including an in vitro fertilization/ intracytoplasmic sperm injection (IVF/ICSI) should be performed for treatment of infertility in such patients $^{7}$.

\section{Semen Abnormalities}

In the majority of patients with SCL, a specific semen profile can be found, which is characterized by poor semen quality due to low sperm motility and poor sperm viability, compared to infertile males with low sperm concentration and low sperm motility in the general population ${ }^{4,6-8,33}$. Among the potential direct causes of semen abnormalities, different toxic substances have been investigated, including proinflammatory cytokines and inflammasome components with leukocytospermia and alterations in the seminal plasma protein profile, as well as dysfunction of accessory glands, lack of coordination within the bladder, hyperactivation of the immune system, and functional failure of the prostate ${ }^{8,34-36}$. In addition, abnormal semen quality may be associated with some indirect factors and lifestyle changes in these patients, such as SCL severity and years post-injury, scrotal hyperthermia, bladder management or techniques of ejaculation $^{8}$. Furthermore, it seems that completeness of spinal injury is an important risk factor for semen parameters because a minority of these patients with incomplete SCL retain normal semen characteristics ${ }^{37}$. Although each bladder management may contribute to lower semen quality, the highest sperm motility (27\%) was found in men treated with intermittent catheterization and lowest sperm motility (5\%) with an indwelling catheter ${ }^{38}$. It seems that scrotal temperature is not associated with poor semen parameters, although it has been hypothesized that prolonged sitting in a wheelchair increases scrotal temperature in $\mathrm{pa}^{-}$ tients with $\mathrm{SCL}^{39}$. Furthermore, it appears that prolonged periods between ejaculations may not negatively affect sperm quality despite previous hypothesis because no improvements in semen parameters after repeated ejaculation by PVS or EEJ have been report$\mathrm{ed}^{40,41}$. However, the method of assisted ejaculation in men with SCL seems to be important considering semen quality because sperm motility may be significantly higher when retrieved by masturbation (36.9\%) than by PVS $(25.9 \%)$ or EEJ $(15 \%)^{42,43}$. Since semen quality usually remains normal during the chronic phase post-injury, long-term cryopreservation cannot be advisable because it can result in essentially immotile sperm with reduced viability due to detrimental effects on mitochondrial activity and DNA fragmentation $^{44-46}$.

\section{Assisted Reproductive Technology}

Intravaginal insemination or "in-home insemination' is usually performed following semen collection by PVS and it is the least invasive technique for the majority of patients with SCL. It would be useful for both partners to be tested prior to the procedure, i.e. the male for the risk of autonomic dysreflexia and for optimal ejaculatory technique, and the female for the absence of tubal or uterine pathology and for the presence of ovulation ${ }^{47,48}$.

Intrauterine insemination (IUI) includes collecting semen from the males with SCL by masturbation, PVS or EEJ combined with separation of motile sperms from the ejaculate in a laboratory to achieve pregnancy in a spontaneous or stimulated cycle. A1though the total motile sperm count of 5 million in the majority of ejaculation-positive PSV or EEJ has been determined in the treatment of infertility in men with SCL, a minimum of only 2 million motile spermatozoa for successful fertilization through IUI has been recently reported. Therefore, it appears that the ejaculate of men with SCL has a sufficient number of motile sperms for IUI and even intravaginal insemina$\operatorname{tion}^{31,49}$

However, in spinal cord injured patients with extremely low total sperm count when fertilization is not successful by the use of IUI, advanced reproductive technologies should be recommended, including ICSI when the number of motile sperm is too low for conventional $\mathrm{IVF}^{13}$. These advanced procedures may be used in men whose ejaculated sperms were retrieved by PVS versus $\mathrm{EEJ}^{9,11,50-52}$, whereas following surgical sperm retrieval from the testicle, the epididymis and vas deferens IVF or ICSI should be mandatory ${ }^{9,12,13}$. However, the choice of current ART for men with SCL is practically controversial because it can be used primarily by surgical sperm retrieval from reproductive tissue and proceeded by IVF/ICSI due to inability of EEJ or PVS training and equipment ${ }^{12,13,31}$. Nevertheless, since a reasonable yield of total mobile sperms can 
be retrieved by the use of PVS or EEJ, it would be desirable to start PVS primarily because the equipment is less expensive and administration is easier than $\mathrm{EEJ}$, and to use intravaginal or $\mathrm{IUI}^{7,31}$.

\section{Pregnancy Outcome}

Intravaginal insemination combined with PVS is an attractive and inexpensive option for assisted conception in couples when the female partner is healthy and the male with SCL has a sufficient total motile sperm count ${ }^{10,48}$. According to various studies, reasonable pregnancy success rates (25\%-75\% per couple) have been reported with reproductive outcomes similar to the general population with the male factor infertility ${ }^{7,9,10,13,48}$.

The reproductive outcome following IUI in such patients depends on semen quality and its efficacy is higher when the total motile sperm count increases; similar to intravaginal insemination, favorable pregnancy rates (24\%-78.6\% per couple) have also been reported $^{7,10,13,53,54}$.

Numerous studies have reported high reproductive potential by use of different assisted methods for sperm retrieval in patients with SCL combined with conventional IVF and ICSI, with pregnancy rates ranging from $15 \%$ to $75 \%$, which are comparable to those in able-bodied sub-fertile men ${ }^{9,11.12,50-52,55,56}$. Nevertheless, the use of TESE for surgical retrieval of fresh sperm instead of ejaculated sperm procedures in combination with ICSI may be advantageous owing to the higher pregnancy rates per couple (74\%). Furthermore, since pregnancy rates per fresh testicular spermICSI are significantly higher than those per frozenthawed sperm-ICSI (64\% vs. 25\%), this approach represents the most promising option for couples with SCL desiring pregnancy ${ }^{56}$. However, despite recommendations against freezing sperm in SCL patients reported by some studies ${ }^{45,46,56}$, it seems that cryopreservation may be advisable owing to the reasonable results (pregnancy rates per couple 50\% vs. 75\%) achieved by use of frozen/thawed sperm obtained after PVS or surgical sperm retrieval combined with $\mathrm{ICSI}^{11}$. Furthermore, analysis of spinal cord injured patients' semen parameters before and after cryopreservation revealed no differences in semen characteristics or in ART cycle results with frozen-thawed spermatozoa of SCL patients compared to the infertile population ${ }^{57}$.

\section{Conclusion}

Despite common impairments of reflexogenic and psychogenic erections in patients with SCL, erectile dysfunction can be managed successfully by the use of phosphodiesterase-5 inhibitors, intracavernosal injections, vacuum devices and penile prostheses. Ejaculatory dysfunction can be treated satisfactorily in most cases by use of several techniques for semen retrieval including penile vibratory stimulation, electroejaculation, prostate massage or surgical procedures. Despite commonly found semen abnormalities in men with spinal injury, reasonable pregnancy rates have been achieved in most of the couples with the use of various assisted methods of semen retrieval combined with the assisted reproductive techniques. However, the choice of assisted technologies for semen retrieval and fertilization is currently controversial. Although some clinicians prefer exclusively surgical sperm retrieval prior to advanced reproductive procedures including IVF and ICSI, it would be desirable to perform sperm retrieval primarily by the use of PVS or EEJ, and if the total sperm count is satisfactory, intravaginal or IUI should be applied. Nevertheless, in cases when the total sperm count is unsatisfactory for insemination, or PVS and EEJ fail, surgical sperm retrieval with IVF or ICSI should be mandatory. Further research is needed to explore various causes and improve semen quality, as well as the methods of assisted ejaculation in patients with SCL.

\section{References}

1. Singh A, Tetreault L, Kalsi-Ryan S, Nouri A, Fehlings MG. Global prevalence and incidence of traumatic spinal cord injury. Clin Epidemiol. 2014;23;6:309-31. doi: 10.2147/CLEP.S68889.

2. Ditunno JF, Cardenas DD, Formal C, Dalal K. Advances in the rehabilitation management of acute spinal cord injury. Handb Clin Neurol. 2012;109:181-95. doi: 10.1016/B978-0-444-52137-8.00011-5.

3. Courtois F, Charvier K. Sexual dysfunction in patients with spinal cord lesions. Handb Clin Neurol. 2015;130:225-45. doi: 10.1016/B978-0-444-63247-0.00013-4.

4. Miranda EP, Gomes CM, de Bessa J Jr, Najjar Abdo CH, Suzuki Bellucci $\mathrm{CH}$, de Castro Filho JE, et al. Evaluation of sex- 
ual dysfunction in men with spinal cord injury using the male sexual quotient. Arch Phys Med Rehabil. 2016;97:947-52. doi: 10.1016/j.apmr.2016.01.005.

5. Morrison BF, White-Gittens I, Smith S, St John S, Bent R, Dixon R. Evaluation of sexual and fertility dysfunction in spinal cord-injured men in Jamaica. Spinal Cord Ser Cases. 2017 May 25;3:17026. doi: 10.1038/scsandc.2017.26. eCollection 2017.

6. Hirsch IH. Optimizing fertility potential in spinal cord injured men. Can J Urol. 2012;19:6437-8.

7. Ibrahim E, Lynne CM, Brackett NL. Male fertility following spinal cord injury: an update. Andrology. 2016;4:13-26. doi: 10.1111/andr.12119.

8. Ibrahim E, Brackett NL, Lynne CM. Advances in the management of infertility in men with spinal cord injury. Asian J Androl. 2016;18:382-90. doi: 10.4103/1008-682X.178851.

9. Leduc BE. Treatment of infertility in 31 men with spinal cord injury. Can J Urol. 2012; 19:6432-6.

10. Kathiresan AS, Ibrahim E, Aballa TC, Attia GR, Lynne CM, Brackett NL. Pregnancy outcomes by intravaginal and intrauterine insemination in 82 couples with male factor infertility due to spinal cord injuries. Fertil Steril. 2011;96:328-31. doi: 10.1016/j.fertnstert.2011.05.019.

11. Bechoua S, Berki-Morin Y, Michel F, Girod S, Sagot P, Fauque P. Outcomes with intracytoplasmic sperm injection of cryopreserved sperm from men with spinal cord injury. Basic Clin Androl. 2013;23:14. doi: 10.1186/2051-4190-23.

12. Raviv G, Madgar I, Elizur S, Zeilig G, Levron J. Testicular sperm retrieval and intra cytoplasmic sperm injection provide favorable outcome in spinal cord injury patients failing conservative reproductive treatment. Spinal Cord. 2013;51:642-4. doi: 10.1038/sc.2013.44.

13. Brackett NL, Lynne CM, Ibrahim E, Ohl DA, Sønksen J. Treatment of infertility in men with spinal cord injury. Nat Rev Urol. 2010;7:162-72. doi: 10.1038/nrurol.2010.7.

14. Everaert K, de Waard WI, Van Hoof T, Kiekens C, Mulliez T, D'herde C. Neuroanatomy and neurophysiology related to sexual dysfunction in male neurogenic patients with lesions to the spinal cord or peripheral nerves. Spinal Cord. 2010;48: 182-91. doi: 10.1038/sc.2009.172.

15. Rizio N, Tran C, Sorenson M. Efficacy and satisfaction rates of oral PDE5 is in the treatment of erectile dysfunction secondary to spinal cord injury: a review of literature. J Spinal Cord Med. 2012;35:219-28. doi: 10.1179/2045772312Y.0000000004.

16. Lebib BA, Laffont I, Boyer F Boiteau F, Dizien O. Intracavernous injection in the treatment of erectile dysfunction in the spinal cord injured patients: about an experience with 36 patients. Ann Readapt Med Phys. 2001;44:35-40.

17. Bodner DR, Haas CA, Krueger B, Sefte AD. Intraurethral alprostadil for treatment of erectile dysfunction in patients with spinal cord injury. Urology. 1999;53:199-202.

18. Denil J, Ohl DA, Smythe C. Vacuum erection device in spinal cord injured men: patient and partner satisfaction. Arch Phys Med Rehabil. 1996;77:750-3.
19. Kim YD, Yang SO, Lee JK, Jung TY, Shim HB. Usefulness of a malleable penile prosthesis in patients with a spinal cord injury. Int J Urol. 2008;15:919-23. doi: 10.1111/j.1442-2042.2008.02115.

20. Henry GD, Wilson SK. Updates in inflatable penile prostheses. Urol Clin North Am. 2007;34:535-47.

21. Lombardi G, Musco S, Wyndaele JJ, Popolo GD. Treatments for erectile dysfunction in spinal cord patients: alternatives to phosphodiesterase type 5 inhibitors? A review study. Spinal Cord. 2015;53:849-54. doi: 10.1038/sc.2015.116.

22. Giuliano F, Clement P. Neuroanatomy and physiology of ejaculation. Annu Rev Sex Res. 2005;16:190-216.

23. Coolen LM, Allard J, Truitt WA. McKenna KE. Central regulation of ejaculation. Physiol Behav. 2004;83:203-15.

24. Sultan R, Vaucher L, Bolyakov A, Paduch DA. Anejaculation. In: Goldstein MS, Schlegel PN, editors. Surgical and Medical Management of Male Infertility. $1^{\text {st }}$ ed. Cambridge: University Press, 2013. pp 105-19.

25. Ohl DA, Quallich SA, Sønksen J, Brackett NL, Lynne CM. Anejaculation and retrograde ejaculation. Urol Clin North Am. 2008;35:211-20. doi: 10.1016/j.ucl.2008.01.014.

26. Chong W, Ibrahim E, Aballa TC, Lynne CM, Brackett NL. Comparison of three methods of penile vibratory stimulation for semen retrieval in men with spinal cord injury. Spinal Cord. 2017;55:921-5. doi: 10.1038/sc.2017.60. Epub 2017 May 30.

27. Castle SM, Jenkins LC, Ibrahim E, Aballa TC, Lynne CM1 Brackett NL. Safety and efficacy of a new device for inducing ejaculation in men with spinal cord injuries. Spinal Cord. 2014;52 Suppl 2:S27-9. doi: 10.1038/sc.2014.110.

28. Brackett NL, Ibrahim E, Iremashvili V, Aballa TC, Lynne CM. Treatment for ejaculatory dysfunction in men with spinal cord injury: an 18-year single center experience. J Urol. 2010; 183:2304-8. doi: 10.1016/j.juro.2010.02.018.

29. Brackett NL, Ead DN, Aballa TC, Ferrell SM, Lynne CM. Semen retrieval in men with spinal cord injury is improved by interrupting current delivery during electroejaculation. J Urol. 2002;167:201-3.

30. Soeterik TF, Veenboer PW, Oude-Ophuis RJ, Lock TM. Electroejaculation in patients with spinal cord injuries: a 21-year, single-center experience. Int J Urol. 2017;24:157-61. doi: 10.1111/iju.13249. Epub 2016 Nov 16.

31. Kafetsoulis A, Brackett NL, Ibrahim E, Attia GR, Lynne CM, et al. Current trends in the treatment of infertility in men with spinal cord injury. Fertil Steril. 2006;86:781-9.

32. Arafa MM, Zohdy WA, Shamloul R. Prostatic massage: a simple method of semen retrieval in men with spinal cord injury. Int J Androl. 2007;30:170-3.

33. Patki P, Woodhouse J, Hamid R, Craggs M, Shah J. Effects of spinal cord injury on semen parameters. J Spinal Cord Med. 2008;31:27-32.

34. Soler JM, Previnaire JG, Mieusset R. Evidence of a new pattern of ejaculation in men with spinal cord injury: ejaculation dys- 
synergia and implications for fertility. Spinal Cord. 2016. doi: 10.1038/sc.2016.78. [Epub ahead of print]

35. da Silva BF, Souza GH, lo Turco EG, Del Giudice PT, Soler TB, Spaine DM, et al. Differential seminal plasma proteome according to semen retrieval in men with spinal cord injury. Fertil Steril. 2013;100:959-69. doi: 10.1016/j.fertnstert.2013.06.009.

36. da Silva BF, Meng C, Helm D, Pachl F, Schiller J, Ibrahim E, et al. Towards understanding male infertility after spinal cord injury using quantitative proteomics. Mol Cell Proteomics. 2016;15:1424-34. doi: 10.1074/mcp.M115.052175.

37. Iremashvili VV, Brackett NL, Ibrahim E, Aballa TC, Lynne CM. A minority of men with spinal cord injury have normal semen quality - can we learn from them? A case-control study. Urology. 2010;76:347-51. doi: 10.1016/j.urology.2009.11.063.

38. Ohl DA, Denil J, Fitzgerald-Shelton K, McCabe M, McGuire EJ, Menge AC, et al. Fertility of spinal cord injured males: effect of genitourinary infection and bladder management on results of electroejaculation. J Am Paraplegia Soc. 1992;15: 53-9.

39. Brackett NL, Lynne CM, Weizman M, Bloch WE, Padron OF. Scrotal and oral temperatures are not related to semen quality of serum gonadotropin levels in spinal cord-injured men. J Androl. 1994;15:614-9.

40. Hamid R, Patki P, Bywater H, Shah PJ, Craggs MD. Effects of repeated ejaculations on semen characteristics following spinal cord injury. Spinal Cord. 2006;44:369-73.

41. Das S, Dodd S, Soni BM, Sharma SD, Gazvani R, Lewis-Jones DI. Does repeated electro-ejaculation improve sperm quality in spinal cord injured men? Spinal Cord. 2006;44:753-6.

42. Brackett NL, Lynne CM. The method of assisted ejaculation affects the outcome of semen quality studies in men with spinal cord injury: a review. Neurorehabilitation. 2000;15:89-100.

43. Kathiresan AS, Ibrahim E, Modh R, Aballa TC, Lynne CM, Brackett NL. Semen quality in ejaculates produced by masturbation in men with spinal cord injury. Spinal Cord. 2012; 50:891-4. doi: 10.1038/sc.2012.71.

44. Iremashvili V, Brackett NL, Ibrahim E, Aballa TC, Lynne CM. Semen quality remains stable during the chronic phase of spinal cord injury: a longitudinal study. J Urol. 2010;184:2073-7. doi: 10.1016/j.juro.2010.06.112.

45. Krebs J, Göcking K, Kissling-Niggli M, Pannek J. Cross-sectional study of the sperm quality in semen samples from spinal cord injured men after long-term cryopreservation. Andrology. 2015;3:213-9. doi: 10.1111/andr.12017.

46. da Silva BF, Borrelli M Jr, Fariello RM, Restelli AE, Del Giudice PT, Spaine DM, et al. Is sperm cryopreservation an option for fertility preservation in patients with spinal cord injury-induced anejaculation? Fertil Steril. 2010;94:564-73. doi: 10.1016/j.fertnstert.2009.03.022.
47. Kathiresan AS, Ibrahim E, Aballa TC. Attia GR, Lynne CM, Brackett NL. Pregnancy outcomes by intravaginal and intrauterine insemination in 82 couples with male factor infertility due to spinal cord injuries. Fertil Steril. 2011;96:328-31. doi: 10.1016/j.fertnstert.2011.05.019.

48. Sønksen J, Fode M, Löchner-Ernst D, Ohl DA. Vibratory ejaculation in 140 spinal cord injured men and home insemination of their partners. Spinal Cord. 2012;50:63-6. doi: 10.1038/sc.2011.101.

49. Cao S, Zhao C, Zhang J, Wu X, Zhou L, Guo X, et al. A minimum number of motile spermatozoa are required for successful fertilisation through artificial intrauterine insemination with husband's spermatozoa. Andrologia. 2014;46:529-34. doi: 10.1111/and.12109.

50. Kathiresan AS, Ibrahim E, Aballa TC, Attia GR, Ory SJ, Hoffman DI, et al. Comparison of in vitro fertilization/intracytoplasmic sperm injection outcomes in male factor infertility patients with and without spinal cord injuries. Fertil Steril. 2011;96:562-6. doi: 10.1016/j.fertnstert.2011.06.078.

51. Schatte EC, Orejuela FJ, Lipshultz LI, Kim ED, Lamb DJ. Treatment of infertility due to anejaculation in the male with electroejaculation and intracytoplasmic sperm injection. J Urol. 2000;163:1717-20.

52. Mc Guire C, Manecksha RP, Sheils P, McDermott TE, Grainger R, Flynn R. Electrocautery stimulation for male infertility secondary to spinal cord injury: the Irish experience in National Rehabilitation Hospital. Urology. 2011;77:83-7. doi: 10.1016/j.urology.2010.07.477.

53. Rutkowski SB, Geraghty TJ, Hagen, DL, Bowers DM, Craven M, Middleton JW. A comprehensive approach to the management of male infertility following spinal cord injury. Spinal Cord. 1999;37:508-14.

54. Pryor JL, Kuneck PH, Blatz SM, Thorp C, Cornwell CE, Carrell DT. Delayed timing of intrauterine insemination results in a significantly improved pregnancy rate in female partners of quadriplegic men. Fertil Steril. 2001;76:1130-5.

55. Gat I, Maman E, Yerushalmi G, Baum M, Dor J, Raviv G, et al. Electroejaculation combined with intracytoplasmic sperm injection in patients with psychogenic anejaculation yields comparable results to patients with spinal cord injuries. Fertil Steril. 2012;97:1056-60. doi: 10.1016/j.fertnstert.2012.01.129.

56. Kanto S, Uto H, Toya M, Ohnuma T, Arai Y, Kyono K. Fresh testicular sperm retrieved from men with spinal cord injury retains equal fecundity to that from men with obstructive azoospermia via intracytoplasmic sperm injection. Fertil Steril. 2009;92:1333-6. doi: 10.1016/j.fertnstert.2008.07.1776.

57. Reignier A, Lammers J, Splingart C, Redhead D, Labat JJ, Mirallié $\mathrm{S}$, et al. Sperm cryopreservation and assisted reproductive technology outcome in patients with spinal cord injury. Andrologia. 2017 Jul 18. doi: 10.1111/and.12833. [Epub ahead of print] 


\section{Sažetak}

\section{POBOLJŠANJE SPOLNE I REPRODUKCIJSKE FUNKCIJE U MUŠKARACA S OŠTEĆENJEM KRALJEŽNIČNE MOŽDINE}

\section{Kasum, S. Orešković, M. Kordić, E. Čehić, D. Hauptman, E. Ejubović A. Lila i G. Smolčić}

Svrha ovoga preglednog članka je analizirati spolne i reprodukcijske funkcije u muškaraca s oštećenjem kralježnične moždine (OKM). Mnoge spolne i reprodukcijske funkcije u ovih bolesnika mogu biti oštećene uključujući vlastitu podcjenjenost, nedostatak spolnog zadovoljstva, erekcijsku i ejakulacijsku disfunkciju te nepravilnosti spermiograma koje karakteriziraju slabija pokretljivost i vijabilnost. Zahvaljujući napretku u fizikalnoj medicini i rehabilitaciji pomiče se glavna usmjerenost na omogućavanje preživljenja takvih bolesnika prema osiguranju kvalitete života, poboljšanju spolne disfunkcije i kasnije reprodukcije. Erekcijska disfunkcija može se liječiti primjenom inhibitora fosfodiesteraze-5, intrakavernoznih injekcija, vakumskih uređaja i proteza za penis. U većine muškaraca s anejakulacijom sjeme se može dobiti postupkom medicinski pomognute ejakulacije primjenom vibracijske stimulacije penisa, elektroejakulacije, masaže prostate ili kirurških zahvata. Premda većina muškaraca s OKM ne uspijeva postići trudnoću na prirodan način, stvaranje potomstva ipak je moguće uvođenjem specijalističkog medicinskog liječenja. Primjenom raznih medicinskih, tehničkih i kirurških tehnika za dobivanje spermija u kombinaciji s metodama za pomognutu oplodnju postignute su zavidne stope trudnoća slično kao u subfertilnih osoba bez tjelesnih oštećenja. Ipak, potrebna su daljnja istraživanja za poboljšanje kvalitete sjemena i metoda za pomognutu ejakulaciju u bolesnika s OKM.

Ključne riječi: Kralježnična moždina, ozljede; Seksualna disfunkcija, fiziološka - terapija; Erektilna disfunkcija - terapija; Sperma, aspiracija; Spermiji, pokretljivost; Trudnoća, učestalost; Kvaliteta života 